the depth of the anterior the camera and the degree of dysplasia $(r=0.41, p<0.05)$, between the axial length of the eye and the degree of dysplasia $(\mathrm{r}=+0.43, \mathrm{p}<0.05)$. Thus, in children with myopia associated with the syndrome of undifferentiated connective tissue dysplasia, unlike children with myopia without signs of dysplasia, we revealed features of biometric indicators that consist in reducing the corneal force of refraction by an average of $4.6 \%$, an increase in the radius of curvature by $5.3 \%$ and corneal diameter by $7.2 \%$, an increase in the depth of the anterior chamber of the eye, on average, by $5.2 \%$, sagittal length of the vitreous body, on average, by $9.2 \%$, and an axial length of the eye, on average, by $4.2 \%$. The obtained data can be useful for diagnosing the prognosis of myopic process and determining the individual treatment tactics.

Key words: myopia, children, biometric indicators, connective tissue dysplasia.

Стаття надійшла до редакції 21.02.2018 p.

B. P. Юревич

Львовский национальный медицинский университет имени Данила Галицкого МЗ Украины - 2. Львов, Украина

УДК $617.7-007.681: 617.735-002: 616.379-008.64-07+577.11-092.9$

\title{
ГЛУТАТИОНОВАЯ СИСТЕМА В ТКАНЯХ ПЕРЕДНЕГО ОТДЕЛА ГЛАЗА ПРИ МОДЕЛИРОВАНИИ ОФТАЛЬМОГИПЕРТЕНЗИИ У ЖИВОТНЫХ СО СТРЕПТОЗОТОЦИНОВЫМ ДИАБЕТОМ
}

\begin{abstract}
У кроликов моделировали офтальмогипертензию (ОГ), стрептозотоциновый диабет (СТД), а также ОГ + СТД. В тканях угла передней камеры глаза изучали уровень окисленной и восстановленной формы глутатиона (GSSG и GSH), дисульфидных и сульфигидрильных (SS- и $\mathrm{SH}-$ групп белков. Установлено, что в группе моделирования ОГ на фоне СТД наблюдались наиболее выраженные изменения глутатионового статуса в изучаемых тканях среди экспериментальных групп. Отмечено снижение восстановительного потенциала глутатиона при сочетанной патологии в тканях угла почти в 2 раза. Изменение здесь количественного состава функциональных групп белков подтверждает повреждение структуры молекул белков в тканях дренажной зоны глаза вследствие усиленного оксидативного стресса при повышенном внутриглазном давлении на фоне диабета. Высокое внутриглазное давление, таким образом, является фактором, усугубляющим метаболические нарушения в тканях глаза при развитии диабета.
\end{abstract}

Ключевые слова: глазная гипертензия, диабет, глутатион, тиоловые группы, угол передней камеры глаза.

В настоящее время диабетическая ретинопатия и первичная глаукома являются одной из лидирующих причин слепоты во всем мире.

Исследованию распространенности этих заболеваний посвящено большое количество работ в разных странах. Однако проблема взаимосвязи сахарного диабета (СД) и первичной открытоугольной глаукомы (ПОУГ), на протяжении многих лет привлекавшая к себе внимание целого ряда отечественных и зарубежных исследователей, и до настоящего времени сохраняет актуальность [4]. Известно, что тяжесть клинической картины при сочетании этих заболеваний более выражена, и, следовательно, прогноз их развития менее благоприятен.
Публикации, касающиеся влияния глаукомы на развитие и течение диабетической ретинопатии, немногочисленны. Проведенные исследования касаются, прежде всего, изучения влияния уровня внутриглазного давления (ВГД) на диабетическую ретинопатию, и в них приводятся достаточно противоречивые данные $[6,2,11]$. Однако, согласно современным представлениям, первичная глаукома - это, прежде всего, оптическая нейропатия. В механизмах поражения нейрональных структур глаза при глаукоме важную роль играет активация процессов свободнорадикального окисления (СРО), что является важнейшим звеном в стрессовых реакциях организма и его адаптации к воздействию гипоксии. При разви- 
тии патологических процессов в организме наблюдается чрезмерная активация процессов СРО, что приводит к избыточному накоплению промежуточных и конечных продуктов перекисного окисления липидов (ПОЛ), которые оказывают патогенное воздействие на организм. Кроме активации свободнорадикальных процессов, в патогенезе глаукомы существенную роль играют механизмы снижения антиоксидантной защиты [7, 12]. Тиоловая система, включающая глутатион и тиоловые группы белков, является одной из наиболее важных неферментативных антиоксидантных систем организма. Повышенный уровень окисленной формы тиоловых групп - дисульфидных групп белков найден в крови пациентов с глаукомой [5]. В экспериментальной работе [8] было установлено, что при моделировании глаукомы у кроликов нарушаются тиоловые системы белков. Автором отмечено снижение уровня тиоловых групп белков сетчатки и повышения уровня дисульфидных групп.

В патогенетических механизмах поражения органа зрения при сахарном диабете процессам гликозилирования и оксидативному стрессу принадлежит ведущая роль $[3,14]$. Имеются доказательства роли свободнорадикальных процессов и, в частности, перекисного окисления липидов в диабетических поражениях сосудов сетчатки и других органов $[1,9]$. Свободные радикалы, дополнительно генерируемые при диабете в процессах аутоокисления глюкозы и гликозилирования белков, могут индуцировать перекисное окисление липидов не только в сосудистой системе, но и в мембранах клеточных и субклеточных структур сетчатки.

Нашими предыдущими исследованиями [10] модели глазной гипертензии на фоне экспериментального диабета у кроликов было показано значительное снижение потенциала глутатионовой системы в сетчатке и ткани зрительного нерва. Изучение этой системы при диабетических изменениях, сопровождающихся фактором риска в виде высокого ВГД, является важным механизмом регулирования этих процессов. Поскольку угол передней камеры - это структура, ответственная за дренаж внутриглазной жидкости, локальный метаболизм в этих тканях существенен для поддержания уровня ВГД. Таким образом, несмотря на очевидную актуальность, вопрос о механизмах взаимного влияния глаукомы и диабетической ретинопатии остается открытым.

Поэтому целью настоящей работы явилось изучение состояния тиоловой системы в тканях угла передней камеры глаза кроликов с моделированием офтальмогипертензии на фоне стрептозотоцинового диабета.

Материалы и методы. Экспериментальные исследования проводились на 34 кроликах породы шиншилла (массой около 3 кг). Работа с животными проводилась с учетом “Европейской конвенции о за- щите позвоночных животных, используемых для экспериментальных и других целей” (Страсбург, 1986) и “Правила выполнения работ с использованием экспериментальных животных”, утвержденных Приказом МЗ Украины и Законом Украины “О защите животных от жестокого обращения” (№ 1759-VI от 15.12.2009).

Подопытные животные были разделены на 4-е группы: 1-я -контрольная группа (8 кроликов), 2-я - животные с диабетом в условиях офтальмогипертензии (10 кроликов), 3-я - животные с диабетом (8 кроликов), 4-я - животные с офтальмогипертензией (8 кроликов). Все группы были разделены на две подгруппы по срокам наблюдения. 1-й срок наблюдения - через 3 недели после моделирования офтальмогипертензии, 2-й - через 6 недель.

Диабет вызывали путем инъекции стрептозотоцина (65 мг на 1 кг массы тела) внутривенно [13]. Через неделю после моделирования диабета у животных на фоне устойчивого уровня глюкозы в крови вызывали офтальмогипертензию.

Для моделирования гипертензии в переднюю камеру глаз вводили 0,25 мл 2 \% раствора метилцеллюлозы [15]. При моделировании офтальмогипертензии животным применяли общую анестезию путем введения кетамина 50 мг/кг, местно в конъюнктивальный мешок за 1 минуту до инъекции вводили глазные капли - 0,5 \% раствор прокаина гидрохлорида. Осуществлялся биомикроскопический контроль для оценки травмы, возможно вызываемой в процессе инъекции. ВГД у кроликов измеряли перед началом эксперимента и в его динамике с использованием пневмотонометра TOPCON CT-80.

Через 3 и 6 недель после моделирования офтальмогипертензии кролики были выведены из эксперимента с помощью летальной дозы пентобарбитола натрия (100 мг на к2, вводимого в маргинальную ушную вену).

В ткани угла передней камеры определяли содержание окисленной и восстановленной формы глутатиона, а также тиоловых и дисульфидных групп белков. Из ткани угла передней камеры глаза, извлеченной при низкой температуре из энуклеированных глаз кроликов, готовили гомогенат с применением $6 \%$ хлорной взвеси в соотношении 1:10 (вес ткани : объем среды для гомогенизации). После центрифугирования при $5^{\circ} \mathrm{C}$ в течение 10 мин при 1000 об/мин надосадочную жидкость нейтрализовали 1,75 М раствором трехзамещенного фосфата калия. В полученном нейтральном экстракте определяли содержание восстановленного и окисленного глутатиона.

Принцип метода определения восстановленного глутатиона. В результате реакции между глутатионом и метилглиоксалем в присутствии фермента глиоксилазы происходит образование конъюгата $\mathrm{S}$-лактоилглутатиона, имеющего максимум поглощения при длине волны 240 нм. 
Принцип метода определения окисленной формы глутатиона состоит в том, что в результате ферментативного восстановления окисленного глутатиона глутатионредуктазой происходит окисление восстановленной формы никотинамидадениндинуклеотидфосфата (НАДФН), убыль которого регистрируют спектрофотометрически при длине волны 340 н $M$.

После окончания определения содержания тиоловой формы глутатиона в ту же кювету добавляли 0,1 мл 11 мМ раствора НАДФН. Перемешивали и регистрировали оптическую плотность при длине волны 340 н $\boldsymbol{M}$. Добавляли 0,01 мл суспензии глутатионредуктазы (0,018 Ед/мл реакционного раствора) и регистрировали оптическую плотность раствора после окончания реакции. Для измерений использовали спектрофотометр СФ-26. Среднее значение коэффициента вариации для указанного диапазона восстановленной формы - 4,0 \%, окисленной формы - 5,0 \%. Содержание восстановленного и окисленного глутатиона выражали в мкмоль/2 ткани.

Принцип метода определения содержания сульфгидрильных групп состоит в определении количества тионитрофенильного аниона, освободившегося в результате взаимодействия 5,5' -дитиобис (2-нитробензойной) кислоты (реактив Элмана) со свободными

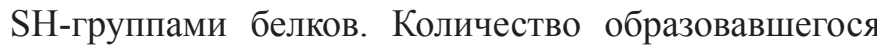
тионитрофенильного аниона прямо пропорционально количеству свободных SH-групп белков, участвующих в реакции. Дисульфидный комплекс, образовавшийся в результате реакции с реактивом Элмана в присутствии дитиотрейтола, также диссоциирует с образованием тионитрофенильного аниона. Сопоставляя содержание свободного тионитрофенильного аниона до и после добавления дитиотреитола (или доведения $\mathrm{pH}$ до 10,5), определяют количество дисульфидных групп в белке. Гомогенат готовили в соотношении 1:10 (вес ткани : объем среды для гомогенизации). Оптическую плотность растворов измеряли при длине волны 412 нм на спектроколориметре “Specol-210” фирмы “Карл Цейс” (Германия). Среднее значение коэффициента вариации - 1,02 \%. Содержание сульфгидрильных и дисульфидных групп выражали в мкмоль/ح исследуемой ткани.

Статистическую достоверность различий определяли по критерию Стьюдента, которая проводилась с помощью пакета SPSS 11.0.

Результаты и их обсуждение. Данные о влиянии моделируемой офтальмогипертензии на содержание восстановленного и окисленного глутатиона в ткани угла передней камеры при экспериментальном диабете у кроликов представлены в табл. 1.

Содержание восстановленного глутатиона в ткани угла передней камеры у животных 2-й груnпь с диабетом и офтальмогипертензией было понижено через 3 недели эксперимента (1-й срок наблюдения) до 53,6 \% ( $<<0,001)$, во 2-й срок наблюдения (через 6 недель эксперимента) - до 42,9 \% ( $<0,001)$ от уровня нормы - 1-й, контрольной группьл.

У кроликов 3-й группы с экспериментальным диабетом содержание восстановленного глутатиона в изучаемой ткани снизилось до 67,9\% от нормы $(\mathrm{p}<0,01)$ в 1-й срок наблюдения и до 52,9\% $(\mathrm{p}<0,001)$ - во 2-й. В меньшей степени от нормы снижалось содержание восстановленного глутатиона в ткани угла передней камеры в 4-й группе животных с офтальмогипертензией до 82,9 \% в 1-й срок и до 73,6 \% - во 2-й срок наблюдения $(\mathrm{p}<0,01)$.

Сравнивая экспериментальные группы между собой, следует отметить, что у животных с гипертензией на фоне диабета уровень содержания восстановленного глутатиона по сравнению с группой животных с диабетом без гипертензии был ниже через 3 недели на 21,1\% и на 18,9 \% - через 6 недель наблюдения $(\mathrm{p}<0,05)$. По сравнению с группой животных с гипертензией без диабета во все сроки исследования у животных 2-й групnы с диабетом в условиях развития гипертензии отмечается снижение содержания восстановленного глутатиона в ткани угла передней камеры. Так, в 1-й срок эта разница составляет 35,3\%, во 2-й срок - 41,7 \% $(\mathrm{p}<0,001)$.

Анализируя изменение уровня окисленной формы глутатиона в ткани угла передней камеры следует отметить, что у животных 2-й группь с диабетом и гипертензией он повысился в 1-й срок до 121,9 \% $(\mathrm{p}<0,05)$. Через 6 недель эксперимента (2-й срок) отметили снижение его содержания до 78,1 \% от нормы $(\mathrm{p}<0,05)$.

У животных 3-й групnь с диабетом содержание окисленной формы глутатиона было повышено в 1-й срок наблюдения до 128,1 \%, во 2-й срок понизилось до $87,5 \%$ относительно нормы $(\mathrm{p}<0,05)$. В сравнительном аспекте разница между 2-й и 3-й группами для этого показателя была незначительной.

Содержание окисленного глутатиона в ткани угла передней камеры в 4-й группе с гипертензией понижалось до 81,3\% в 1-й срок и до 75 \% во 2-й сравнительно с нормой $(\mathrm{p}<0,05)$. При сравнении этой группы со 2-й группой (с диабетом и гипертензией) отмечено повышение содержания окисленного глутатиона в ткани угла передней камеры во 2-й групnе в 1-й срок на $50 \%(\mathrm{p}<0,001)$, во 2-й - разница была незначительной.

Мы отметили снижение уровня окисленной формы глутатиона в изучаемой ткани глаза на более поздних этапах эксперимента, тогда как на ранних сроках отмечалось его повышение. Это может быть связано с ухудшением процессов синтеза этого коферментного антиоксиданта либо с нарушением проницаемости мембран клеток для этого вещества и выходом его в камерную влагу. Однако восстановительный потен- 
Таблица 1

Влияние гипертензии на содержание восстановленного и окисленного глутатиона в ткани угла передней камеры при экспериментальном диабете у кроликов

\begin{tabular}{|c|c|c|c|c|c|}
\hline \multirow{2}{*}{$\begin{array}{c}\text { Биохимические } \\
\text { показатели }\end{array}$} & \multirow[b]{2}{*}{$\begin{array}{c}\text { Группьл } \\
\text { животных }\end{array}$} & \multirow{2}{*}{$\begin{array}{c}\text { Статистические } \\
\text { показатели }\end{array}$} & \multicolumn{3}{|c|}{ Условия эксперимента/группь } \\
\hline & & & $\begin{array}{c}\text { Норма } \\
\text { 1-я группа }\end{array}$ & 1-ц̌ срок & 2-ц̌ срок \\
\hline \multirow{3}{*}{$\begin{array}{c}\text { Восстановленный } \\
\text { глутатион } \\
\text { (мкмоль/2 ткани) }\end{array}$} & $\begin{array}{c}\text { Диабет+ } \\
\text { гипертензия } \\
\text { 2-я группа }\end{array}$ & $\begin{array}{c}\mathrm{M} \pm \mathrm{m} \\
\mathrm{p} \\
\% \\
\mathrm{p} 1 \\
\% 1 \\
\mathrm{p} 2 \\
\% 2\end{array}$ & $\begin{array}{c}1,40 \pm 0,10 \\
- \\
100,0\end{array}$ & $\begin{array}{c}0,75 \pm 0,05 \\
<0,001 \\
53,6 \\
<0,05 \\
78,9 \\
<0,001 \\
64,7\end{array}$ & $\begin{array}{c}0,60 \pm 0,04 \\
<0,001 \\
42,9 \\
<0,05 \\
81,1 \\
<0,001 \\
58,3\end{array}$ \\
\hline & $\begin{array}{c}\text { Диабет } \\
\text { 3-я группа }\end{array}$ & $\begin{array}{c}\mathrm{M} \pm \mathrm{m} \\
\mathrm{p} \\
\%\end{array}$ & $\begin{array}{c}1,40 \pm 0,10 \\
- \\
100,0 \\
\end{array}$ & $\begin{array}{c}0,95 \pm 0,07 \\
<0,01 \\
67,9 \\
\end{array}$ & $\begin{array}{c}0,74 \pm 0,05 \\
<0,001 \\
52,9 \\
\end{array}$ \\
\hline & $\begin{array}{c}\text { Гипертензия } \\
\text { 4-я группа }\end{array}$ & $\begin{array}{c}\mathrm{M} \pm \mathrm{m} \\
\mathrm{p} \\
\%\end{array}$ & $\begin{array}{c}1,40 \pm 0,10 \\
- \\
100,0\end{array}$ & $\begin{array}{c}1,16 \pm 0,07 \\
<0,05 \\
82,9\end{array}$ & $\begin{array}{c}1,03 \pm 0,06 \\
<0,01 \\
73,6\end{array}$ \\
\hline \multirow{3}{*}{$\begin{array}{c}\text { Окисленный глутатион } \\
\text { (мкмоль/2 ткани) }\end{array}$} & $\begin{array}{c}\text { Диабет+ } \\
\text { гипертензия } \\
\text { 2-я группа }\end{array}$ & $\begin{array}{c}\mathrm{M} \pm \mathrm{m} \\
\mathrm{p} \\
\% \\
\mathrm{p} 1 \\
\% 1 \\
\mathrm{p} 2 \\
\% 2 \\
\end{array}$ & $\begin{array}{c}0,32 \pm 0,02 \\
- \\
100,0\end{array}$ & $\begin{array}{c}0,39 \pm 0,02 \\
<0,05 \\
121,9 \\
>0,05 \\
95,1 \\
<0,001 \\
150,0 \\
\end{array}$ & $\begin{array}{c}0,25 \pm 0,02 \\
<0,05 \\
78,1 \\
>0,05 \\
89,3 \\
>0,05 \\
104,2 \\
\end{array}$ \\
\hline & $\begin{array}{c}\text { Диабет } \\
\text { 3-я группа }\end{array}$ & $\begin{array}{c}\mathrm{M} \pm \mathrm{m} \\
\mathrm{p} \\
\%\end{array}$ & $\begin{array}{c}0,32 \pm 0,02 \\
- \\
100,0\end{array}$ & $\begin{array}{l}0,41 \pm 0,03 \\
<0,05 \\
128,1\end{array}$ & $\begin{array}{c}0,28 \pm 0,02 \\
>0,05 \\
87,5\end{array}$ \\
\hline & $\begin{array}{c}\text { Гипертензия } \\
\text { 4-я группа }\end{array}$ & $\begin{array}{c}\mathrm{M} \pm \mathrm{m} \\
\mathrm{p} \\
\%\end{array}$ & $\begin{array}{c}0,32 \pm 0,02 \\
- \\
100,0\end{array}$ & $\begin{array}{c}0,26 \pm 0,02 \\
>0,05 \\
81,3\end{array}$ & $\begin{array}{c}0,24 \pm 0,01 \\
<0,05 \\
75,0\end{array}$ \\
\hline
\end{tabular}

Примечания:

p - уровень значимости различий данных по отношению к группе “Норма";

$\mathrm{p}_{1}$ - уровень значимости различий данных по отношению к группе “Диабет”;

$\mathrm{p}_{2}$ - уровень значимости различий данных по отношению к группе "Гипертензия"

циал глутатиона в ходе эксперимента, тем не менее, снижался. Приведенные в табл. 2 расчетные данные соотношения восстановленной и окисленной формы глутатиона свидетельствуют о том, что дисбаланс глутатионового статуса в ткани угла передней камеры при моделировании офтальмогипертензии у кроликов с экспериментальным диабетом сохранялся весь период наблюдения. Исходя из данных приведенного индекса, баланс восстановленной и окисленной формы глутатиона был снижен в группе с гипертензией и диабетом почти в 2 раза, чуть ниже он был в группе только с диабетом. Таким образом, именно сочетание экспериментального диабета и высокого внутриглазного давления вызвало максимальное ухудшение глутатионового статуса в изучаемой ткани угла передней камеры глаза.

Данные о влиянии глазной гипертензии на содержание тиоловых и дисульфидных групп в ткани угла передней камеры при экспериментальном диабете у кроликов представлены в табл. 3. Из полученных нами данных видно, что содержание тиоловых групп в ткани угла передней камеры экспериментальных животных 2-й группьы с диабетом и гипертензией было понижено через 3 недели наблюдения до 76,6 \%, через 6 недель - до 66,1 \% по отношению к норме ( $<<0,001)$.

Изучая уровень тиоловых групп в ткани угла передней камеры в 3-й группе животных с воспроизведенным диабетом, можно отметить, что их показатели понижались до 81,6 \% в 1-й срок $(p<0,05)$ и до 75,2 - во 2-й срок наблюдения сравнительно с нормой $(\mathrm{p}<0,01)$. Сравнительный анализ 2-й и 3-й групn показал, что у животных с диабетом и офтальмогипертензией отмечается уменьшение содержания тиоловых групп по сравнению с группой животных с диабетом без гипертензии, однако эти изменения не были статистически значимыми ( $>00,05)$.

Содержание тиоловых групп в ткани угла передней камеры животных 4-й груnпы с офтальмогипертензией понижалось незначительно (p>0,05) в 1-й срок и до 82,4\% - во 2-й относительно нормы $(\mathrm{p}<0,05)$. Сравнение данных 4-ц̌ и 2-ц̌ групn показало, что этот показатель во 2-й группе был ниже, чем в 4-й на 20,8 \% в 1-й срок и практически не изменился во 2 -й экспериментальный срок $(p<0,05)$. 
Таблииа 2

Влияние гипертензии на отношение восстановленной формы глутатиона к окисленной форме глутатиона в ткани угла передней камеры при экспериментальном диабете у кроликов

\begin{tabular}{|c|c|c|c|c|}
\hline \multirow{2}{*}{ Биохимические показатели } & \multirow{2}{*}{$\begin{array}{c}\text { Группьь } \\
\text { животных }\end{array}$} & \multicolumn{3}{|c|}{ Условия эксперимента } \\
\hline & & Норма & $1-и ̆ с р о к$ & $2-\check{u}$ срок \\
\hline \multirow{3}{*}{$\begin{array}{c}\text { Восстановленный глутатион / окисленный } \\
\text { глутатион }\end{array}$} & Диабет+гипертензия & 4,38 & 1,92 & 2,4 \\
\hline & Диабет & 4,38 & 2,32 & 2,64 \\
\hline & Гипертензия & 4,38 & 4,46 & 4,29 \\
\hline
\end{tabular}

Таблииа 3

Влияние гипертензии на содержание белковых групп в ткани угла передней камеры глаза при экспериментальном диабете у кроликов

\begin{tabular}{|c|c|c|c|c|c|}
\hline \multirow{2}{*}{ Биохимические показатели } & \multirow{2}{*}{$\begin{array}{c}\text { Группьы } \\
\text { животных }\end{array}$} & \multirow{2}{*}{$\begin{array}{c}\text { Статистические } \\
\text { показатели }\end{array}$} & \multicolumn{3}{|c|}{ Условия эксперимента/групп } \\
\hline & & & Норма & $1-\check{u}$ срок & $2-\ddot{u} с р о к$ \\
\hline \multirow{3}{*}{$\begin{array}{c}\text { Тиоловые группы } \\
\text { (ммоль/2) }\end{array}$} & $\begin{array}{c}\text { Диабет + } \\
\text { гипертензия }\end{array}$ & $\begin{array}{c}\mathrm{M} \pm \mathrm{m} \\
\mathrm{p} \\
\% \\
\mathrm{p} 1 \\
\% 1 \\
\mathrm{p} 2 \\
\% 2\end{array}$ & $\begin{array}{c}1,25 \pm 0,07 \\
- \\
100,0\end{array}$ & $\begin{array}{c}0,95 \pm 0,06 \\
<0,01 \\
76,0 \\
>0,05 \\
93,1 \\
<0,05 \\
79,2\end{array}$ & $\begin{array}{c}0,82 \pm 0,06 \\
<0,001 \\
66,1 \\
>0,05 \\
87,2 \\
<0,05 \\
79,6\end{array}$ \\
\hline & Диабет & $\begin{array}{c}\mathrm{M} \pm \mathrm{m} \\
\mathrm{p} \\
\%\end{array}$ & $\begin{array}{c}1,25 \pm 0,07 \\
- \\
100,0\end{array}$ & $\begin{array}{c}1,02 \pm 0,06 \\
<0,05 \\
81,6\end{array}$ & $\begin{array}{c}0,94 \pm 0,06 \\
<0,01 \\
75,2\end{array}$ \\
\hline & Гипертензия & $\begin{array}{c}\mathrm{M} \pm \mathrm{m} \\
\mathrm{p} \\
\%\end{array}$ & $\begin{array}{c}1,25 \pm 0,07 \\
- \\
100,0\end{array}$ & $\begin{array}{c}1,20 \pm 0,07 \\
>0,05 \\
96,0\end{array}$ & $\begin{array}{c}1,03 \pm 0,07 \\
<0,05 \\
82,4\end{array}$ \\
\hline \multirow{3}{*}{$\begin{array}{c}\text { Дисульфидные группы } \\
\text { (ммоль/2) }\end{array}$} & $\begin{array}{c}\text { Диабет + } \\
\text { гипертензия }\end{array}$ & $\begin{array}{c}\mathrm{M} \pm \mathrm{m} \\
\mathrm{p} \\
\% \\
\mathrm{p} 1 \\
\% 1 \\
\mathrm{p} 2 \\
\% 2\end{array}$ & $\begin{array}{c}0,50 \pm 0,03 \\
- \\
100,0\end{array}$ & $\begin{array}{c}0,64 \pm 0,03 \\
<0,05 \\
128,0 \\
>0,05 \\
108,5 \\
>0,05 \\
118,5\end{array}$ & $\begin{array}{c}0,72 \pm 0,04 \\
<0,01 \\
144,0 \\
>0,05 \\
118,0 \\
<0,05 \\
120,0\end{array}$ \\
\hline & Диабет & $\begin{array}{c}\mathrm{M} \pm \mathrm{m} \\
\mathrm{p} \\
\%\end{array}$ & $\begin{array}{c}0,50 \pm 0,03 \\
- \\
100,0\end{array}$ & $\begin{array}{c}0,59 \pm 0,03 \\
<0,05 \\
118,0\end{array}$ & $\begin{array}{c}0,61 \pm 0,04 \\
<0,05 \\
122,0\end{array}$ \\
\hline & Гипертензия & $\begin{array}{c}\mathrm{M} \pm \mathrm{m} \\
\mathrm{p} \\
\%\end{array}$ & $\begin{array}{c}0,50 \pm 0,03 \\
- \\
100,0\end{array}$ & $\begin{array}{c}0,54 \pm 0,04 \\
>0,05 \\
108,0\end{array}$ & $\begin{array}{c}0,60 \pm 0,03 \\
<0,05 \\
120,0\end{array}$ \\
\hline
\end{tabular}

Примечания:

p - уровень значимости различий данных по отношению к группе “Норма";

$\mathrm{p}_{1}$ - уровень значимости различий данных по отношению к группе “Диабет”;

$\mathrm{p}_{2}$ - уровень значимости различий данных по отношению к группе "Гипертензия”

Наряду с понижением в экспериментальных группах у кроликов уровня сульфгидрильных (тиоловых) групп у животных отмечен рост уровня дисульфидных групп в тканях угла передней камеры. Содержания дисульфидных групп в исследуемой ткани экспериментальных животных 2-й группы с диабетом и гипертензией составило в 1-й срок наблюдения $128,0 \%$ ( $<0,05)$, во 2-й срок - 144,0 \% по отношению к норме $(\mathrm{p}<0,01)$.

Уровень дисульфидных групп в ткани угла передней камеры в 3-й групnе животных с диабетом увеличивался до $118,0 \%$ через 3 недели наблюдения $(\mathrm{p}<0,05)$, до $122,0 \%$ - через 6 недель сравнительно c нормой $(\mathrm{p}<0,05)$. В изучаемые сроки у животных с диабетом в условиях развития офтальмогипертензии отмечается увеличение содержания дисульфидных групп по сравнению с группой животных с диабетом без гипертензии. Так, в 1-й срок возрастание составляет $8,5 \%(\mathrm{p}>0,05)$, во 2-й срок - 18,0 \% (p<0,05).

В ткани угла передней камеры содержание дисульфидных групп у животных 4-й группы с офтальмогипертензией было повышено в 1-й срок до 108,0 \%, во 2-й срок составило $120,0 \%$ относительно нормы $(\mathrm{p}<0,05)$. При сравнении этого показателя между $2-\check{u}$ и 4-й группами отмечено, что у животных с диабетом и гипертензией он был выше на $18,5 \%$ в 1-й срок и на $20,3 \%$ - во 2-й $(\mathrm{p}<0,05)$.

Таким образом, экспериментальные исследования показали, что в тканях угла передней камеры глаза 
кроликов отмечается нарушение баланса функциональных групп белков. Содержание тиоловых групп в этих тканях снижалось в динамике, и через 6 недель после моделирования офтальмогипертензии оно было ниже, чем через 3 недели. В отношении дисульфидных групп отмечалась противоположная картина: их содержание в тканях угла передней камеры глаз животных в динамике эксперимента повышалось. При этом максимальные изменения были нами отмечены в группе животных при сочетанном моделировании глазной гипертензии и стрептозотоцинового диабета.

\section{Выводы}

1. Высокое внутриглазное давление на фоне экспериментального диабета у кроликов ухудшает состояние тиоловой дезинтоксикационной системы в тканях угла передней камеры. В группе животных с глазной гипертензией и стрептозотоциновым диабетом уровень восстановленной формы глутатиона в этих тканях снижался в динамике, и через 6 недель наблюдения это снижение составило 57,1 \% в сравнении с нормой. Относительно группы с диабетом без гипертензии этот показатель был ниже на $19 \%$.

2. Уровень соотношения восстановленной и окисленной формы глутатиона говорит о том, что дисбаланс глутатионового статуса в ткани угла передней камеры при моделировании офтальмогипертензии у кроликов с экспериментальным диабетом сохранялся весь период наблюдения. Это свидетельствует о снижении в этой ткани восстановительного потенциала глутатиона при сочетанной патологии почти в 2 раза.

3. Изменение количественного состава функциональных групп белков в изучаемых тканях подтвердил факт повреждения структуры молекул белков в тканях дренажной зоны глаза вследствие усиленного оксидативного стресса при повышенном внутриглазном давлении на фоне диабета.

4. Высокое внутриглазное давление, таким образом, является фактором, усугубляющим при развитии диабета метаболические нарушения в организме, а именно - в тканях глаза.

\section{Литература}

1. Алексеев И. Б. О некоторых звеньях патогенеза диабетической ретинопатии при сахарном диабете 2-го типа и роли антиоксидантов / И. Б. Алексеев, С. А. Кочергин, И. В. Воробьева, Л. Г. Михалева // Вестник офтальм. - 2013. - Т. 129, № 3. - С. 89-93.

2. Астахов Ю. С. Является ли сахарный диабет фактором риска развития первичной открытоугольной глаукомы/ Ю. С. Астахов, И. С. Крылова, Ф. Е. Шадричев // Клиническая офтальм. - 2006. - Т. 7, № 3. - С. 91-94.

3. Балаболкин М. И. Роль гликирования белков, окислительного стресса в патогенезе сосудистых осложнений при сахарном диабете / М. И. Балаболкин // Сахарный диабет. - 2002. - № 4. - С. $5-16$.

4. Воробьева И. В. Глаукома и диабетическая ретинопатия у пациентов с сахарным диабетом 2-го типа / И. В. Воробьева, Е. В. Щербакова // Офтальмология. - 2014. - Т. 11 (3). - С. 4-12.

5. Газизова И. Р. Состояние окислительно-восстановительной системы у больных первичной открытоугольной глаукомой / И. Р. Газизова // Казанск. Медиц. журн. - 2012. - Т. 93, № 3. C. $488-490$.

6. Имантаева М. Б. Сахарный диабет и первичная глаукома / М. Б. Имантаева // Казанск. офтальмолог. журн. - 2010. - № 4 (35). - С. 22-27.

7. Кравчук E. А. Роль свободнорадикального окисления в патогенезе заболеваний глаз / Е. А. Кравчук // Вестник офтальмологии. - 2004. - № 5. C. $48-51$.

8. Сердюк B. H. Состояние тиол-дисульфидной системы белков сетчатки и зрительного нерва при развитии экспериментальной глаукомы / В. Н. Сердюк // Проблеми екологічної та медичної генетики і клінічної імунології: 3б. наук. праць. 2011. - Вип. 6 (108). - С. 239-245.

9. Смирнова О. М. Свободнорадикальное окисление и антиоксидантная защита при сахарном диабете / О. М. Смирнова, Т. В. Никонова; под ред. И. И. Дедова. - М: Медицина, 2003. - 40 с.

10. Юревич В. Р. Состояние тиоловой системы в сетчатке и зрительном нерве при моделировании открытоугольной глаукомы (гипертензии) у животных со стрептозотоциновым диабетом / В. Р. Юревич // Офтальмология. - 2015. - № 2. C. 221-231.

11. Ellis J. D. Should diabetic patients be screened for glaucoma / J. D. Ellis, C. J. MacEwen, A. D. Morris // Br. J. Ophthalmol. - 1999. - Vol. 83. - P. 369-372.

12. Izzotti $A$. The role of oxidative stress in glaucoma / A. Izzotti, A. Bagnis, S. C. Sacca // Mutat. Res. 2006. - Vol. 612. - P. 105-114.

13. Mir M. S. Streptozotocin Induced Acute Clinical Effects in Rabbits / M. S. Mir, M. M. Darzi, O. K. Baba [et al.] // Iranian J. Pathology. - 2015. - Vol. 10, № 3. - P. 206-213.

14. Wolff S. P. Protein glycation and oxidative stress in diabetes mellitus and ageing / S. P. Wolff, Z. Y. Jiang, J. V. Hundt // Free Radic. Biol. Med. - 1991. - Vol. 10. - P. 339-352.

15. Zhu M. D. Development of experimental chronic intraocular hypertension in the rabbit / M. D. Zhu, F. Y. Cai // Australian and New Zeland J Ophthalmol. - 1992. - Vol. 20. - P. 225-234. 


\title{
ГЛУТАТІОНОВА СИСТЕМА В ТКАНИНАХ ПЕРЕДНЬОГО ВІДДІЛУ ОКА ПРИ МОДЕЛЮВАННІ ОФТАЛЬМОГІПЕРТЕНЗІЇ У ТВАРИН ЗІ СТРЕПТОЗОТОЦИНОВИМ ДІАБЕТОМ
}

\author{
В. Р. Юревич
}

У кроликів моделювали офтальмогіпертензію (ОГ), стрептозотоциновий діабет (СТД), а також ОГ+СТД. У тканині кута передньої камери ока вивчали рівень окисленої і відновленої форми глутатіону, дісульфідних та сульфгідрильних груп білків. Встановлено, що в групі моделювання ОГ на тлі СТД у досліджуваній тканині серед експериментальних груп спостерігалися найбільш виражені зміни глутатіонового статусу. Відзначено зниження відновного потенціалу глутатіону при поєднаній патології в тканині кута майже в 2 рази. Зміна кількісного складу функціональних груп білків підтверджує ушкодження структури молекул білків у тканинах дренажної зони ока внаслідок посиленого оксидативного стресу при підвищеному внутрішньоочному тиску на фоні діабету. Високий внутрішньоочний тиск, таким чином, $є$ фактором, який збільшує метаболічні порушення в тканинах ока при розвитку діабету.

Ключові слова: гіпертензія ока, діабет, глутатіон, тіолові групи, кут передньої камери ока.

\section{GLUTATHIONE SYSTEM IN THE TISSUES OF THE ANTERIOR PART OF THE EYE IN THE MODELING OF OPHTHALMIC HYPERTENSION IN ANIMALS WITH STREPTOZOTOCIN DIABETES}

\author{
V. R. Yurevych \\ Lviv National Medical University named after Danylo Halytskiy of the Ministry of Public Health of Ukraine \\ Lviv, Ukraine
}

The problem of the relationship between diabetes mellitus and primary open-angle glaucoma is still topical today. It is known that the severity of the clinical picture with the combination of these diseases is more pronounced and, therefore, the prognosis of their development is much less favorable. There are several common intracellular mechanisms that are typical for development of both diabetes and primary glaucoma. Some of these are free radical mechanisms, the excessive activation of which initiates the formation of oxidative stress. The antioxidant system in the body regulates this process. The thiol system, which includes glutathione and thiol groups of proteins, is one of the most important non-enzymatic antioxidant systems in the body. Therefore, the aim of this work was to study the state of the thiol system in the anterior chamber tissues of the rabbit eye with the modeling of ophthalmohypertension on the background of streptozotocin diabetes. Materials and methods. The studies were carried out on 4 groups of rabbits, which were modeled for ophthalmic hypertension (OG), streptozotocin diabetes (STD), OG+STD. The 4th group consisted of intact animals (control). For hypertension modeling $0.25 \mathrm{ml}$ of a $2 \%$ solution of methylcellulose was injected into the anterior eye chamber, diabetes was induced by injection of streptozotocin $(65 \mathrm{mg}$ per $1 \mathrm{~kg}$ of body weight) intravenously. In the anterior chamber angle tissue, the concentration of oxidized and reduced form of glutathione, as well as thiol and disulfide groups of proteins, was determined. Observations were carried out 3 and 6 weeks after the OG simulation.

Results and discussion. It was found that the most pronounced changes in the glutathione status in the studied tissue among the experimental groups were observed in group OG on the background of STD. In the group OG+STD the level of oxidized form of glutathione in the anterior chamber angle tissue was decreased in dynamics and after 6 weeks of observation it was $57.1 \%$ of the control. Comparing with the diabetes group without hypertension, this indicator was statistically lower by $19 \%$. Decrease of the redox potential of glutathione in the tissue at a combined pathology almost 2 times was noted. In the studied eye tissue, a decrease in the level of thiol groups and an increase in disulphide groups were observed. After 6 weeks of observation in rabbits with OG+STD, SH-groups levels were decreased to $66 \%$, SS-groups were increased to $144 \%$ in comparison with the control.

The change in the quantitative composition of protein functional groups confirms the damage of the protein molecules structure in the eye drainage zone tissues due to increased oxidative stress during increased intraocular pressure on the background of diabetes. High intraocular pressure, therefore, is a factor exacerbating metabolic disturbances in the eye tissues in the development of diabetes.

Key words: eye hypertension, diabetes, glutathione, thiol groups, angle of anterior chamber of the eye.

Стаття надійшла до редакції 22.01.2018 р. 